\title{
原著銊炎古典手技『焼山火』による施術，局所 および経絡上の温度変化について
}

\author{
王財 源* 遠 藤 宏 豊田 住 江 \\ 河内明北出利勝兵頭 正義
}

要旨『焼山火』は中国古来より刺銊手技のひとつとして用いられてき た補法の変法手技である。刺銊時において，熱感や腫れぼさ覚え，虚 証で泠之症の患者に古くから行われてきた。では果たして刺針時にお いて皮膚表面温度・深部温度・血流量がどのように変化をするか，古 来より伝えられてきた方法を用いて観察を行なった。今回は特に中国 の老中医師に指導を賜わり研究を進め, 臨床的試験の結果, 皮膚温度 ・深部温度に上昇傾向が認められた。特に遠位部における皮虐温度と 深部温度は，刺銊後 40 分目には $1.0^{\circ} \mathrm{C}$ 以上の上昇が認められた。局所に おいても $0.5^{\circ} \mathrm{C}$ 以上の温度上昇が認められた。

\section{I は じめに}

補瀉手技は鍼炎治療を行う上での基本原則で, 中国の伝統刺針手技のひとつに「焼山火」と「透天涼」 がある。中国の古典である《神応経》また素問の《針 解編》そして《霊枢》の九銊十二原や《難経》にもその 内容が記載され，1439年除鳳の《針炎大全》中の《金 針賦》に補瀉手技として詳細に論述される。以後こ の《金針賦》は補瀉手技の基本論述書とされ，揚継 州氏によってまとめられた。

特に「焼山火」は刺鍼部位に熱感や腫れぼったさ を覚之，中国での数多くの研究報告より，体温の 上昇や血糖・血漿成分への影響が述べられている。 今回は中国の報告より示唆を得て, 中国の伝統 手法「焼山火」のみを行い，局所ならびに遠位部の

* WANG Cai Yuan 大阪医科大学麻酔科ペインクリニック 共同研究者: Hiroshi ENDO, Sumie TOYOTA, Akira KaWACHI, Toshikatsu KITADE, Masayoshi HyOdo 大阪医 科大学麻酔科ぺインクリニック

Key Words：鍼刺激, 中国鍼法, 皮虐温度変化
刺銊前後における皮虐温度と深部温度，また血流 量を調查したので報告する。

\section{II 研 究方 法}

【対象】大阪医科大学麻酔科ぺインクリニック に通院する26歳，31歳，56歳，62歳，73歳の 5 名 の腰痛患者に行った。

【測定装置】テルモ社製コアテンプCTM-201・ 表面・深部温度モニタ一を使用し，血流量はアド バンス社製レーザー組織(微小循環)血流量計ALF 2100 を用いた。

【測定部位】足底中央やや前方で，第 $2 \cdot 3$ 中 足骨間の湧泉穴相当部位と, 大腿骨大転子と仙骨 管裂孔を結んだ外方 $1 / 3$ と内方 $2 / 3$ の境界線で中国 の環跳穴の $3 \mathrm{~cm}$ ところに設定した。

【刺激誘発方法】広州中医学院付属広東省中医 院針炎科の劉炳権主任の指導により行なった。つ まり，切皮後，少し鍼を止めてから上下に 3 回鍼 を動かし，鍼を天部に戻して気をうかがう，得気 後, 天・人・地の三部に分けて提挿補法を各 9 回 ずつ同一方向に回旋しながら行い，施術者が3 回 
呼吸するのをまって鍼を人部へ進め，再度同様な 方法を繰り返してから地部まで銊を進める。地部 で同様な操作が終了したら，素早く天部まで銊を 戻して鍼体を引き倒し銊先を経脈の流注の方向に 向けて置鍼する。また抜鍼後はすみやかに鍼孔を 押圧する，これが1回の操作である(Fig.1)。刺鍼 誘発部位は患側部の環跳穴一穴のみで行い，60ミ リ・34号のステンレス製中国銊を使用し 2 分間刺 激とした。

\section{III 研 究 結 果}

刺銊前後の局所ならびに遠隔部の皮膚表面温度 と樑部温度を測定した。
【局所】無刺激群と比較すると, 焼山火群の皮 虐温度上昇が認められ(Table.1)，最高が20分後 $0.64^{\circ} \mathrm{C}$ まで上昇した $(\mathrm{P}<0.05)$ 。染部温度では最高 が40分後に $0.46^{\circ} \mathrm{C}$ まで上昇した $(\mathrm{P}<0.05) 。$

【遠位】無刺激群と比較すると, 焼山火群の皮 䖉温度上昇が認められ(Table.2), 刺激值後より上 昇し，40分後に $1.06^{\circ} \mathrm{C}$ であった $(\mathrm{P}<0.05)$ 。深部温 度においても，刺激直後より上昇傾向を示し，40

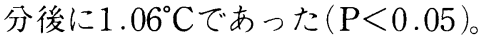

局所および遠位部ともに皮膚温度と深部温度の 上昇が認められたが，局所は遠位部ほどの高い值 を示すことはなかった。

血流量 (Table.3)では, 局所においては意外に反

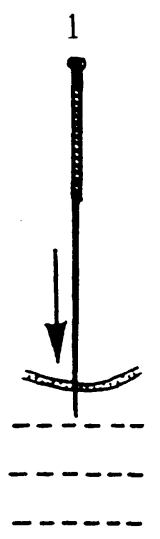

(切皮)
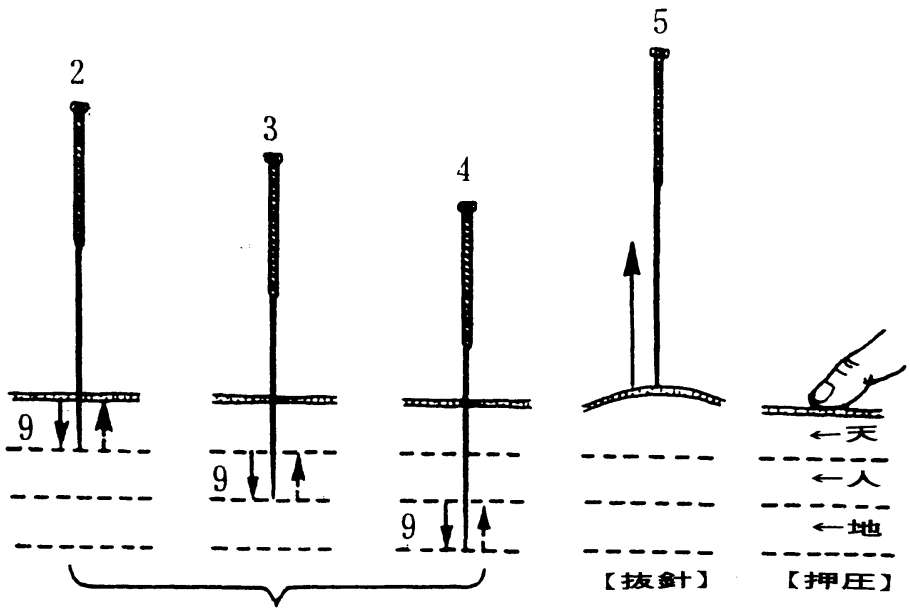

1 度(提抑法各9回ずつ回加)

Fig. 1 焼山火誘発方法

Table. 1

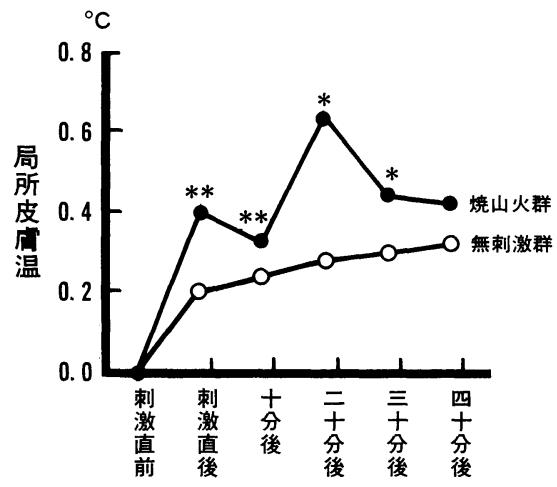

局所皮凨温度無刺激群と焼山火群との比較

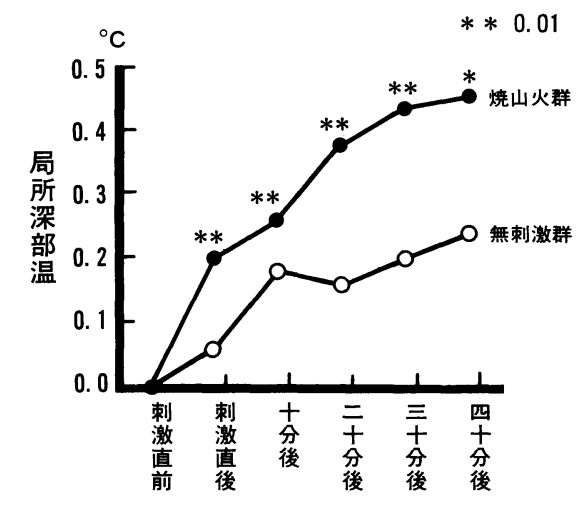

局所深部温度無刺激群と焼山火との比較 
Table. 2

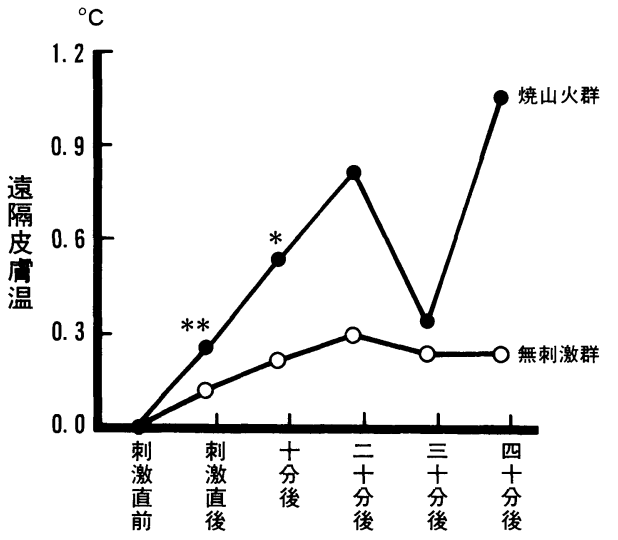

遠隔皮成温度無刺激群と焼山火群との比較

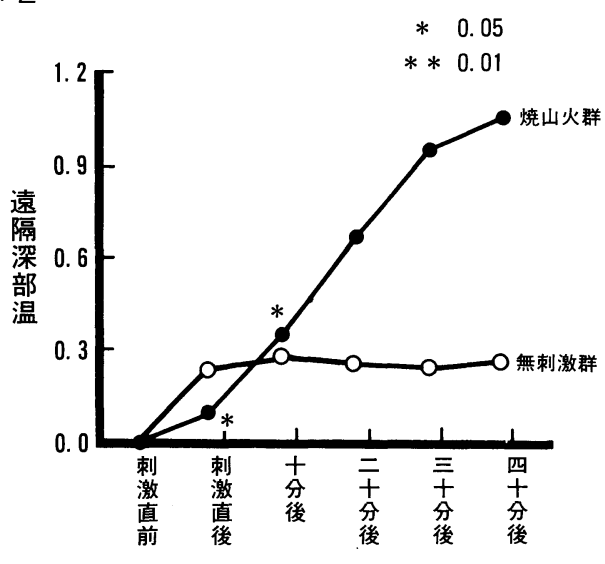

遠隔深部温度無刺激群と焼山火群との比較

Table. 3 無刺激群と焼山火群との血流量

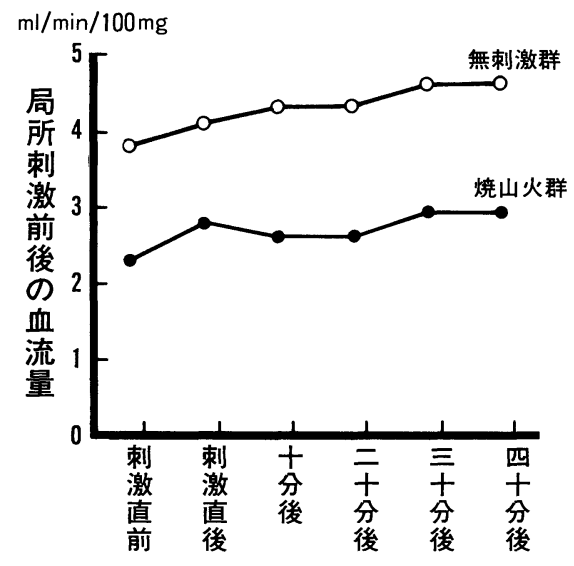

応を示すことはなかったが，遠位部において若干 の増加傾向を示した。

\section{IV 考察}

中国河北医学院基礎医学研究所の董承流氏は, 60例の患者に対して指先脈波計を用いて合谷穴に 「焼山火」法を行ったところ, 局所より末梢部に血 管拡張反応が著しく認められ，表面温度の上昇や， 肢体容積曲線の上昇があったことを報告している。 肢体容積曲線の法則的な変化は, 単に複合経公に 補瀉の手技を加之る場合に発生するだけではなく， 健康者や患者の特定した 1 穴に手技を施す際にも

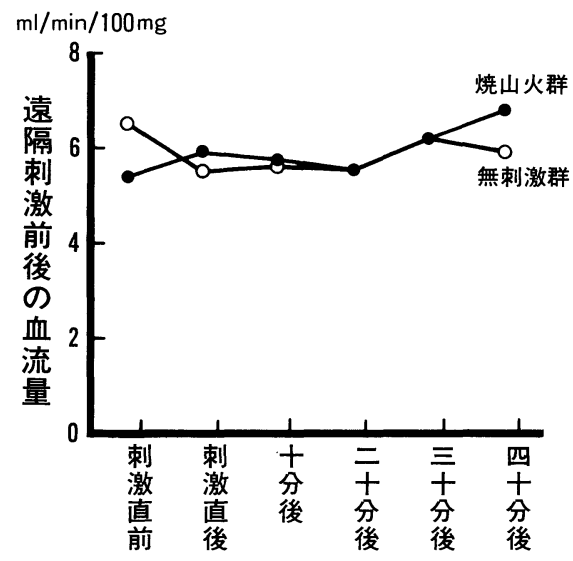

現われる。しかも健康者に特にハッキリと現われ， そして大動脈の緊張度の変化に対してもその脈拍 伝播速度の減速により血管緊張が下降した。これ は健康者, 患者の如何なる状態に扔いても現われ る変化であることを述べている。本実験において も遠位部(末梢)に特に著明な温度上昇 $\left(1.06^{\circ} \mathrm{C}\right)$ が 認められ，中国の報告と同様な結果が出た。

また，上海の陸瘦㴖氏も血管の収繀運動また拡 張運動の他に，血管の上昇㧍よび血漿成分への影 響が認められたとの報告がある。

循経感覚伝導現象の誘発実験中においても, 経 絡線上に沿って皮䖉炎の出現や，貧血状態ならび 
に一過性の体温上昇と，それに伴う部分的な発汗 現象があることはよく知られている。

“気”の操作により生体内部にさまざまな反応を 繰り広げることが可能な一本の鍼に要求されるの は，刺鍼時の操作技術である。

「焼山火」は提按・進退・浅深・拇指捻転時の方 向と，呼吸ならび九陽六陰の配合によって行なわ れ，“緊按慢提”“先浅後深”“三進一退”の技法が主 流となる。《䨋枢・始終編》に”専意一神, 精気之分, 母聞人声, 以収其精, 必一其神, 令志在針”（鍼を 刺すときは，静かなところで病人の精神状態をよ く観察する。部屋を閉じて精神を統一し，人声な どを聞いて心を乱すことなく，ただ一途に精神を 鍼に集中しなければならない)とあり,刺鍼時の基 本がここに記されている。これらによって手技の 実現が導き出されるのである。また，術者の運気 も必要なために，呼吸法の訓練即ぢ気”を練り上 げることも，手技誘発に欠かすことができないU とつである。

『標幽賦』に気が至るというのは, 釣飭が魚に吞 み込まれて浮き沈みするようなものである。気が まだ至らないとは，奥深い幽堂にいるようなもの である。と刺鍼中における得気感覚が記されてい るが，現在のところこの得気を目安にする基準が 無いために，伝統的に継承されたものを受け継ぐ しかなく，今後は検討の必要がある。

以上のことより"気”によって出現した客観的な 現象は, 単に自律神経作用によって起こり得ると は言いがたい，1984年の第二回全国針尒針麻酔シ ンポジウムで，中国の孟昭威氏はその席上に於い て，鍼尒の治療効果を，第一平衡系統に神経系， 第二平衡系統に植物神経系に，そして第三平衡系 統を経絡とし，独自の組織で運営され，それを『整 体区域全消息論』を提起し,研究がさらに進められ， 新経絡循環図が完成する予定だ。現在まで多くの 研究が行なわれているが，視点を変えるだけであ る者は神経系作用と言い，ある者は気・経絡の作 用と言う。この両者の接点を導きだしたのが，孟 氏の説であった。

今後，逆手技である「透天涼」法を用いて冷え感 や，媣部温度・表面温度また血流量等の調査をを行 い,「燒山火」との比較検討を進めたい。

\section{$\mathrm{V}$ 結 び}

刺鍼刺激前後における，局所皮膚温度・深部温 度と, 遠位部の皮虞温度・深部温度を観察した結 果，遠位部において著明な温度上昇がみとめられ た。局所と比較して遠位(末梢)の温度上昇が著し いのは，中国での報告と同様な結果が出た。血流 量も遠位部における血流量に増加傾向が見られた だけであった。補法の変法「焼山火」と泠瀉法の変 法「透天涼」は，現在多くの注目を浴びている古典 手技ひとつで，われわれがよく耳にする手法であ り，今後この両者の温度上昇に及ぼす影響につい ての比較検討を行なっていきたい。

\section{参考文献}

1）陸瘦燕ほか：焼山火と透天涼の刺針手技が体温 と血液成分に与える影響，上海中医薬雑誌，(9) ;33. (1965)

2) 董承流ほか：焼山火と透天涼が血管運動に対す る作用，天津医薬雑誌，(5·6);334. (1963)

3) 北出利勝, 兵頭正義ほか：明瞭な経絡現象を呈 する一症例について(第一報), 全日本銊炎学会 雑誌 33(1);50～60.(1983)

4) 王 財源：子午流注の納子法が示す日時経脈流 注の循環図について, 東洋医学とぺインクリニ ック Vol. 13PP;59〜62. (1983)

$5 ）$ 鄭 魁山：臨床常用時の刺針技法の紹介, 中医 雓誌，(2);13. (1963)

( T569 大阪府高槻市大学町2-7 大阪医大附属病院麻酔科) 